\title{
Manisa ili ilköğretim öğrencilerinde sigara içme prevalansı
}

\author{
Çayan ALKAÇ ${ }^{1}$ \\ Pınar ÇELIK ${ }^{2}$ \\ Beyhan Cengiz ÖZYURT ${ }^{5}$ \\ Ayşın ŞAKAR COŞKUN ${ }^{2}$ \\ Aylin Özgen ALPAYDIN ${ }^{3}$ \\ Tuğba GÖKTALAY \\ Murat DEMET ${ }^{4}$ \\ Ayşe Arzu \\ YORGANCIOĞLU ${ }^{2}$
}

${ }^{1}$ Batman Bölge Devlet Hastanesi, Göğüs Hastalıkları Kliniği, Batman, Türkiye

${ }^{1}$ Clinic of Chest Diseases, Batman District State Hospital, Batman, Turkey

2 Manisa Celal Bayar Üniversitesi Tıp Fakültesi, Göğüs Hastalıkları Anabilim Dalı, Manisa, Türkiye

${ }^{2}$ Department of Chest Diseases, Faculty of Medicine, Manisa Celal Bayar University, Manisa, Turkey

${ }^{3}$ Dokuz Eylül Üniversitesi Tıp Fakültesi, Göğüs Hastalıkları Anabilim Dalı, İzmir, Türkiye

${ }^{3}$ Department of Chest Diseases, Faculty of Medicine, Dokuz Eylul University, Izmir, Turkey

${ }^{4}$ Manisa Celal Bayar Üniversitesi Tıp Fakültesi, Psikiyatri Anabilim Dalı, Manisa, Türkiye

${ }^{4}$ Department of Psychiatry, Faculty of Medicine, Manisa Celal Bayar University, Manisa, Turkey

${ }^{5}$ Manisa Celal Bayar Üniversitesi Tıp Fakültesi, Halk Sağlığı Anabilim Dalı, Manisa, Türkiye

${ }^{5}$ Department of Public Health, Faculty of Medicine, Manisa Celal Bayar University, Manisa, Turkey

\section{ÖZET}

\section{Manisa ili ilköğretim öğrencilerinde sigara içme prevalansı}

Giriş: Bu çalışmada ilimizdeki ilköğretim öğrencilerinde sigara içme prevalansının, içimi etkileyen faktörlerin belirlenmesi ve Temmuz 2009'da yürürlüğe giren sigara yasağına karşı öğrencilerin tutumlarının değerlendirilmesi amaçlanmıştır.

Materyal ve Metod: Tanımlayıcı nitelikteki araştırmanın evrenini ilimiz merkez ilköğretim okulları 6-7-8. sınıflarında bulunan 8236'sı kent ve 4937'si gecekondu olmak üzere 13.173 öğrenci oluşturdu. Örneklem sayısı, ilimizde daha önce bulunan sigarayı ilk kez deneme prevalansı \% 17.5 baz alınarak 831 kişi, rastgele seçim yöntemi kullanılarak 6 kent ve 3 gecekondu olmak üzere 9 okul olarak belirlendi. Sigara içme, etkileyen faktörler, sigara içmenin etkileri ve ailelerinin sigara içme durumları gibi soruları içeren anket formu hazırlandı. Belirlenen 9 okuldan toplam 615 öğrenciye anket uygulandı. Araştırmanın verileri SPSS 14.0 bilgisayar istatistik paket programı kullanılarak değerlendirildi. İstatistiksel analizlerde tanımlayıcı istatistikler (yüzde dağılımı, ortalama, standart sapma), ki-kare ve bağımsız gruplarda t-testi kullanıldı.

Bulgular: Öğrencilerin \%47'si kızdı. Sigara deneme prevalansı $\% 23.5$ (kent okullarında \%16, gecekondu okullarında \%35), sigara içme prevalansı ise \%7.1 (kent okullarında \% 1.7, gecekondu

\section{Yazıșma Adresi (Address for Correspondence)}

\section{Dr. Pınar ÇELIK}

Manisa Celal Bayar Üniversitesi Tıp Fakültesi, Göğüs Hastalıkları Anabilim Dalı, MANISA - TÜRKIYE

e-mail: pinarcelik@yahoo.com 
okullarında \% 15.7) olarak saptandı. Sigara deneme yaşı $10.04 \pm 2.3^{\prime}$ tü. Öğrencilerin \%86.6'sının sigara yasağını desteklediği, \% 43.3'ünün sigara paketleri üzerindeki uyarı yazılarının etkili olduğunu düşündüğü ve \%35.2'sinin sigara dumanına maruz kaldıkları saptandı.

Erkek cinsiyet, yaş, sosyoekonomik durum, ailenin eğitim durumu, aile bireyi ve en yakın arkadaşın sigara içmesinin öğrencinin sigara içmesinde önemli risk faktörleri olduğu görüldü.

Sonuç: Sigara içmeye başlama yaşının erken olması sigarayla mücadele çalışmalarının ilköğretim okullarına ve özellikle sigara içme prevalansının yüksek olduğu gecekondu bölgelerine yoğunlaştırılmalıdır.

Anahtar kelimeler: Sigara; ilköğretim; prevalans

\section{SUMMARY}

\section{Smoking prevalence of elementary school students in Manisa}

Introduction: In this study it is aimed to evaluate the prevalence of smoking, factors affecting smoking status, and the attitudes of the elementary school students towards the smoking prohibition law which was approved in July 2009, in city.

Materials and Methods: The universe of this descriptive study was $6^{\text {th }}-7^{\text {th }}-8^{\text {th }}$ class, 8236 urban and 4937 semi-urban, total 13.173 elementary schools students in city center. Study population was determined on the basis of a previous study in which the smoking trial prevalence was found 17.5\%, 831 students in 6 urban 3 semi-urban, total 9 schools were chosen randomly. A questionnaire was prepared investigating smoking status, the effects of smoking and family history. Among the 9 chosen schools, the questionnaire was applied to 615 students. SPSS 14.0 statistical package was used.

Results: Forty-seven percentages of the students were female. Prevalence of smoking trial was found $23.5 \%(16 \%$ in urban, $35 \%$ in semi-urban schools) while the prevalence of smoking was $7.1 \%$ (1.7\% in urban, $15.7 \%$ in semi-urban schools). Mean age of first smoking trial was $10.04 \pm 2.3$. The smoking prohibition law was supported by $86.6 \%$ of the students, the warnings on the cigarette package was thought to be effective by $43.3 \%$ students and $35.2 \%$ of the students were exposed to passive smoke. Male gender, social status, education level of the family, smoker family member or close friends were found to be important risk factors for smoking prevalence of the students.

Conclusion: The early onset of smoking should guide the smoking struggle be concentrated in elementary school especially in semiurban areas where the smoking prevalence is high.

Key words: Smoking; elementary school; prevalence

\section{Giriş}

Gelişmiş ve gelişmekte olan ülkelerde gençler arasında tütün epidemisi önemli bir halk sağlığı sorunu olarak tanımlanmaktadır (1). Sigara üreticilerinin hedef kitlesinin özellikle gençler olduğu bilinmektedir. Sigara üreticileri için, genç nüfusun fazla olduğu, gelişmekte olan veya gelişmemiş ülkeler uygun pazarlardır. Erken yaşta sigara içmeye başlayan kişilerde ileri yaşlarda içtikleri sigara sayısında artış olduğu da bilinmektedir $(2,3)$.

Sigara içme özellikle nedenleri açısından önemli bir psikososyal sorundur. Okul yaşlarındaki çocuklarda sigara kullanımını, sosyal öğrenme doğrudan etkilemektedir. Arkadaş baskısı, anne baba ya da kardeşlerin sigara içimi, öğrencilerin öğretmen, sanatçı, sporcu gibi sevdikleri ve önemsedikleri kişilerin sigara içmeleri, öğrencilerin sigaraya başlamasında özendirici rol oynamaktadır $(4,5)$.

Bu çalışmada, il merkezinde ilköğretim öğrencilerinde sigara içme prevalansının ve sigara içimini etkileyecek faktörlerin belirlenmesi ve de Temmuz 2009 'da yürür- lüğe giren tütün mamüllerinin zararlarının önlenmesine dair yasaya karşı öğrencilerin tutumlarının değerlendirilmesi amaçlandı.

\section{MATERYAL ve METOT}

\section{Araştırmanın Tipi}

Çalışma, il merkezi ilköğretim öğrencilerinde sigara içme prevalansı ve sigara içimini etkileyen faktörlerin saptanması amacıyla altıncı, yedinci ve sekizinci sınıf öğrencilerinde yürütülmüş olan kesitsel tipte bir çalışmadır.

\section{Araştırmanın Evreni}

Araştırmanın evrenini, kent merkezinde bulunan ilköğretim okullarının altıncı, yedinci ve sekizinci sınıf öğrencilerinden oluşan 8236'sı kent ve 4937'si gecekondu olmak üzere toplam 13.173 öğrenci oluşturmaktadır. Çalışmanın bu sınıflar düzeyinde yapılmasının nedeni, bu yaş grubunun sigaraya başlama açısından risk grubunu oluşturması ve sigarayla mücadelede asıl müdahele edilmesi gereken grup olmasıdır. 


\section{Araştırmanın Örneklemi}

Araşıırmanın yapılacağı evren yerleşim yerini belirlemek için tabakalı rastgele örnek seçim yöntemi kullanılmıştır. Epi İnfo 2000 programıyla daha önce ilimizde yapılan bir çalışmada sigarayı ilk kez deneme prevalansı olan \%17.5 baz alınarak (\%2 hata payı ile örnekleme girecek öğrenci sayısı) 831 olarak belirlenmiştir.

Kent merkezinde altıncı, yedinci ve sekizinci sınıfların toplam şube sayısı göz önünde bulundurularak her şubede ortalama 30 öğrenci olduğu belirlenmiştir. Toplam öğrenci sayısının şube sayısına bölünmesi sonucunda $(831 / 30=2.7)$ çalışmaya 27 şubenin alınmasına karar verilmiştir. Kız, erkek oranları eşit olduğundan cinsiyete göre tabakalandırma yapılmamıştır. Araştırmaya alınacak okullar tabakalı rastgele örneklem yöntemi kullanılarak belirlenmiştir. Kent merkezindeki okullar kent ve gecekondu olarak iki tabakaya ayrılmıştır. Çalışmaya alınması planlanan 27 şubeden 18 adet şube kentsel ilköğretim okullarından, dokuz adet şube de gecekondu ilköğretim okullarından alınmıştır. Kentsel bölgelerdeki 6. sınıflardan 6 şube, 7 . sınıflardan 6 şube, 8. Sınıflardan 6 şube, gecekondu bölgelerindeki 6. sınıflardan 3 şube, 7. sınıflardan 3 şube ve 8 . sınıflardan 3 şube olmak üzere toplam 27 şube çalışmaya alınmıştır.

Hangi okullarda çalışmanın yapılacağına her tabakada yer alan okullardan rastgele sayılar tablosundan yararlanarak karar verilmiştir. Daha sonra örneğe çıkan okulların sınıflarından rastgele örneklem yöntemiyle eğitim ve öğretimi aksatmamak amacıyla okul yöneticisinin görüşü de alınarak hangi sınıflarla görüşme yapılacağı belirlenmiştir.

\section{Veri Toplama Araçları}

Araştırmada 46 sorudan oluşan bir anket formu kullanılmıştır. Dünya Sağlık Örgütü (DSÖ)'nün Health Behaviour in School Aged Children (HBSC) 2001 yılı anket formundan yararlanılarak hazırlanan anket formunun ilk 14 sorusu; yaş, cinsiyet, anne-baba eğitimi ve sosyal güvence durumunu incelemeye yönelik sosyo-demografik bilgileri içermektedir. Daha sonraki sorular ise; öğrencilerin sigarayı deneme yaşları, sigara içmeyi sürdürme, sigaraya başlama nedenleri, ortalama sigara içme miktarları, aile tutumları, sigara yasağına karşı tutumlarına ilişkin bilgileri içermektedir.

\section{Uygulama Süreci}

Üniversitemiz Araştırma Hastanesi Etik Kurulu ve il Milli Eğitim Müdürlüğü'nden gerekli izinler alınmıştır. Ankete katılacak öğrenciler çalışma hakkında bilgilendirilerek gönüllü katılımları sağlanmıştır. Öğrencilere gözlem altında anket uygulanmış, anlaşılmayan sorular yüz yüze görüşülmüş̧ür.

\section{Araştırma Verisinin Analizi}

Araştırmanın verileri SPSS 14.0 bilgisayar istatistik paket programı kullanılarak değerlendirilmiştir. istatistiksel analizler; numerik değişkenlerin değerlendirilmesi ortalama, standart sapma kullanılarak, kategorik değişkenlerin değerlendirilmesi sayı, yüzde dağılımı gibi tanımlayıcı istatistikler kullanılarak yapılmıştır. Çözümleyici istatistikler; kategorik değişkenlerin (cinsiyet, sınıf, okul yerleşim yeri vb.) bağımlı değişkenlerle (sigarayı deneme, sigara kullanımı) ilişkisini değerlendirme ki-kare testi ve numerik (sayısal) değişkenlerin (anne yaşı, baba yaşı, kardeş sayısı, sigaraya başlama yaşı gibi) gruplar arasındaki değişimini incelemede de student's t-testi (bağımsız gruplarda t-testi) ve çok değişkenli analizlerde lojistik regresyon modeli kullanılmıştır. Anlamlılık düzeyi olarak $p<0.05$ olarak kabul edilmiştir.

\section{BULGULAR}

Toplam 831 öğrenciden 696'sı ankete katıldı. Yüz otuz dört öğrenci ise anket günlerindeki devamsızlık durumları ya da aile onayı alınamadığı için ankete katılamadı. Kent okullarından ankete katılan öğrencilerin $\% 50.2$ 'sini, gecekondu okullarından katılanların ise $\% 41.9^{\prime}$ unu kız öğrenciler oluşturmaktaydı. Öğrencilerin \%37.8'i altıncı, \%31.3'ü yedinci, \%30.9'u sekizinci sınıf öğrencisiydi. Kent okullarından ankete katılan öğrencilerin \%38.9'u altıncı, \%30.7'si yedinci, \%30.4'ü sekizinci sınıf, gecekondu okullarından katılanların ise \%36'sı altıncı, \%32.4'ü yedinci, \%31.6'sı sekizinci sınıf öğrencisiydi. Öğrencilerin yaş ortalaması kent okullarında $12.96 \pm 0.8$, gecekondu okullarında $13.24 \pm 1.3$ olarak saptandı $(p<0.05)$.

Kent okullarından katılan öğrencilerin \%90.4'ünün, gecekondu okullarından katılan öğrencilerin \%76.8'inin sağlık güvencesi vardı, aralarında anlamlı istatistiksel fark saptandı $(p<0.05)$.

Ortalama kardeş sayısı kent okullarında $2.35 \pm 1.2$, gecekondu okullarında $4.75 \pm 2.4^{\prime} \mathrm{dü}(p=0.00)$. 
Araştırmada sigarayı ilk deneme yaşı ortalaması genel olarak $10.04 \pm 2.3$, kent okullarında $9.7 \pm 2.5$, gecekondu okullarında $10.38 \pm 2.4$ olarak saptandı $(p>$ 0.05).

Sınıf düzeyine göre sigarayı deneme prevalansına bakıldığında sınıf düzeyi arttıkça sigarayı deneme oranlarının da arttığı görüldü $(p<0.00)$. Cinsiyete göre değerlendirildiğinde erkeklerde kız öğrencilere göre daha yüksek sigara deneme oranları saptandı $(p<0.00)$. Okul yerleşim yerine göre sigarayı deneme oranları kent okullarında \%16, gecekondu okullarında $\% 35$ olarak bulundu $(p<0.00)$. Cinsiyete göre sigarayı deneme oranları kent ve gecekondu okullarında değerlendirildiğinde, kent okullarında kızlarla erkekler arasında anlamlı fark gözlenmezken gecekondu okullarında belirgin farklılık gözlendi $(p<0.001)$. Sigara deneme oranları sınıf düzeyine göre gecekondu ve kent olarak karşılaştıııldığında ise 7. sınıflar dışında bütün gruplarda gecekondu okullarında anlamlı olarak yüksek deneme oranları saptandı $(p<0.05)$. Anne ve baba eğitimine göre sigara deneme oranları karşılaştırıldığında ise tek tek gruplar arasında fark gözlenmezken kent-gecekondu ayrımı yapılmaksızın yapılan değerlendirmede anne ve baba eğitim düzeyi yükseldikçe sigara deneme oranlarının anlamlı olarak azaldığı gözlendi. Anne mesleğine göre sigara deneme oranları değerlendirildiğinde ise sadece kent okullarında annesi ev hanımı olanlarda diğerlerine göre sigara içme oranı daha yüksek saptandı $(p<0.01)$ (Tablo 1).

Ankete katılan öğrencilerin aile ve arkadaşlarının sigara içme durumuna göre sigara deneme oranları değerlendirildiğinde en iyi arkadaşı ve kardeşi sigara içenlerde sigarayı deneme oranları anlamlı olarak yüksek saptandı $(\mathrm{p}<0.05)$ (Tablo 2).

Öğrencilerin sigara ile ilişkili hastalıklar konusunda bilgi düzeyleri değerlendirildiğinde tüm hastalıklarda kent ve gecekondu okulları (kent okullarında daha yüksek) ve sigara içen ve içmeyen öğrenciler arasında (sigara içenlerde daha yüksek) anlamlı fark saptandı $(\mathrm{p}<0.05)$.

Ankete katılan öğrencilerin sigara yasağına karşı tutumları değerlendirildiğinde kent okullarındaki öğrencilerin \%92.2'sinin, gecekondu okullarındaki öğrencilerin ise \%77.8'inin yasağı desteklediği gözlendi $(p<0.001)$. Sigara paketleri üzerindeki uyarı

Tablo 1. Araştırmaya katılan öğrencilerin bazı sosyodemografik özelliklerine göre sigarayı deneme oranlarının karşıllaştırılması

\begin{tabular}{|c|c|c|c|c|c|c|c|}
\hline & & \multicolumn{5}{|c|}{ Sigarayı deneme } & \multirow[b]{3}{*}{$\mathbf{p}$} \\
\hline & & \multicolumn{2}{|c|}{ Kent (\%) } & \multirow[b]{2}{*}{$\mathbf{p}$} & \multicolumn{2}{|c|}{ Gecekondu (\%) } & \\
\hline & & Evet & Hayır & & Evet & Hayır & \\
\hline \multirow[t]{2}{*}{ Cinsiyet* } & $\mathrm{K}_{\mathrm{IZ}}$ & 13.7 & 86.3 & \multirow{2}{*}{0.214} & 24.1 & 75.9 & \multirow{2}{*}{0.001} \\
\hline & Erkek & 18.2 & 81.8 & & 43.6 & 56.4 & \\
\hline \multirow[t]{3}{*}{ Sinıf* } & 6 & 10.3 & 89.7 & \multirow{3}{*}{0.039} & 26.3 & 73.7 & \multirow{3}{*}{0.002} \\
\hline & 7 & 19.5 & 80.5 & & 30.7 & 69.3 & \\
\hline & 8 & 19.7 & 80.3 & & 50.6 & 49.4 & \\
\hline \multirow[t]{3}{*}{ Baba eğitimi* } & Okur yazar değil-okur yazar & 20.0 & 80.0 & \multirow{3}{*}{0.359} & 39.3 & 60.7 & \multirow{3}{*}{0.394} \\
\hline & ilköğretim & 18.8 & 81.2 & & 33.0 & 67.0 & \\
\hline & Lise ve üzeri & 13.7 & 86.3 & & 45.5 & 54.0 & \\
\hline \multirow[t]{3}{*}{ Anne eğitimi* } & Okur yazar değil-okur yazar & 25.0 & 75.0 & \multirow{3}{*}{0.340} & 39.3 & 60.7 & \multirow{3}{*}{0.193} \\
\hline & ilköğretim & 14.1 & 85.9 & & 28.6 & 71.4 & \\
\hline & Lise ve üzeri & 17.6 & 82.4 & & 50.0 & 50.0 & \\
\hline \multirow[t]{5}{*}{ Baba mesleği* } & Memur & 13.6 & 86.4 & \multirow{5}{*}{0.541} & 29.7 & 70.3 & \multirow{5}{*}{0.087} \\
\hline & İşçi & 12.9 & 87.1 & & 53.3 & 46.7 & \\
\hline & Emekli & 22.2 & 77.8 & & 50.0 & 50.0 & \\
\hline & İşsiz & 14.3 & 85.7 & & 33.3 & 66.7 & \\
\hline & Küçük esnaf/zaanatkar & 18.9 & 81.1 & & 35.4 & 64.6 & \\
\hline \multirow[t]{2}{*}{ Anne mesleği* } & Ev hanımı & 13.6 & 86.4 & \multirow{2}{*}{0.019} & 34.9 & 65.1 & \multirow{2}{*}{0.327} \\
\hline & Çalışıyor & 23.3 & 76.7 & & 50.0 & 50.0 & \\
\hline
\end{tabular}


Tablo 2. Araştırmaya katılan öğrencilerin aile ve arkadaşlarının sigara içmesine göre sigara deneme oranlarının karşılaştırılması

\begin{tabular}{|c|c|c|c|c|c|c|c|}
\hline & & \multicolumn{5}{|c|}{ Sigarayı deneme } & \multirow[b]{3}{*}{$\mathbf{p}$} \\
\hline & & \multicolumn{2}{|c|}{ Kent $(\%)$} & \multirow[b]{2}{*}{$\mathbf{p}$} & \multicolumn{2}{|c|}{ Gecekondu (\%) } & \\
\hline & & Evet & Hayır & & Evet & Hayır & \\
\hline \multirow[t]{2}{*}{ Anne } & İçiyor & 23.6 & 76.4 & \multirow{2}{*}{0.013} & 35.4 & 64.6 & \multirow{2}{*}{0.979} \\
\hline & İçmiyor & 13.4 & 86.6 & & 35.6 & 64.4 & \\
\hline \multirow[t]{2}{*}{ Baba* } & İçiyor & 19.4 & 80.6 & \multirow{2}{*}{0.045} & 37.0 & 63.0 & \multirow{2}{*}{0.534} \\
\hline & İçmiyor & 12.2 & 87.8 & & 33.3 & 66.7 & \\
\hline \multirow[t]{2}{*}{ Kardeş* } & İçiyor & 40.0 & 60.0 & \multirow{2}{*}{0.000} & 52.5 & 47.5 & \multirow{2}{*}{0.014} \\
\hline & İçmiyor & 13.4 & 86.6 & & 32.3 & 67.7 & \\
\hline \multirow[t]{2}{*}{ En iyi arkadaş* } & İçiyor & 40.5 & 59.5 & \multirow{2}{*}{0.000} & 66.3 & 33.7 & \multirow{2}{*}{0.000} \\
\hline & İçmiyor & 12.7 & 87.3 & & 21.9 & 78.1 & \\
\hline
\end{tabular}

Tablo 3. Öğrencilerin sigarayla ilgili bilgi ve tutumlarının karşılaştırılması

\begin{tabular}{|c|c|c|c|c|c|}
\hline & & \multicolumn{2}{|c|}{ Okul yerleşim yerine göre } & \multirow[b]{2}{*}{ Toplam } & \multirow[b]{2}{*}{$\mathbf{p}$} \\
\hline & & $\begin{array}{c}\text { Kent } \\
(n=424)(\%) \\
\end{array}$ & $\begin{array}{c}\text { Gecekondu } \\
(\mathrm{n}=272)(\%)\end{array}$ & & \\
\hline \multirow[t]{2}{*}{ Sigara yasağını } & Evet destekliyorum & 92.2 & 77.8 & 86.6 & \multirow{2}{*}{0.0005} \\
\hline & Hayır desteklemiyorum & 7.8 & 22.2 & 13.4 & \\
\hline \multirow[t]{2}{*}{ Genç yaşta içilen sigara } & Evet, alışkanlık yapar & 97.4 & 91.5 & 95.1 & \multirow{2}{*}{0.0001} \\
\hline & Hayır, alışkanlık yapmaz & 2.6 & 8.5 & 4.9 & \\
\hline \multirow[t]{2}{*}{ Sigara paketindeki uyarı yazıları } & Etkili & 32.9 & 59.6 & 43.3 & \multirow{2}{*}{0.001} \\
\hline & Etkili değil & 67.1 & 40.4 & 56.7 & \\
\hline \multirow[t]{2}{*}{ Pasif içicilik nedir? } & Biliyorum & 62 & 30.5 & 49.7 & \multirow{2}{*}{0.0004} \\
\hline & Bilmiyorum & 38 & 69.5 & 50.3 & \\
\hline
\end{tabular}

Tablo 4. Öğrencilerin sigaraya başlama nedenleri

\begin{tabular}{|c|c|c|c|}
\hline Başlama nedeni & $\begin{array}{c}\text { Kent } \\
(n=7)(\%)\end{array}$ & $\begin{array}{c}\text { Gecekondu } \\
(n=42)(\%)\end{array}$ & $\begin{array}{l}\text { Toplam } \\
(n=49)\end{array}$ \\
\hline Merak & 66.7 & 25.5 & 36.2 \\
\hline Arkadaş ısrarı & 27.8 & 19.6 & 21.7 \\
\hline Üzüntü & 5.6 & 17.6 & 14.5 \\
\hline Özenti & 0.0 & 11.8 & 8.7 \\
\hline Yalnızlık hissi & 0.0 & 9.8 & 7.2 \\
\hline Merak + özenti & 0.0 & 3.9 & 2.9 \\
\hline Merak + arkadaş ısrarı & 0.0 & 2.0 & 1.4 \\
\hline Üzüntü + merak & 0.0 & 5.9 & 4.3 \\
\hline Arkadaş ısrarı + karizmatik görünme & 0.0 & 2.0 & 1.4 \\
\hline Merak + yalnızlık hissi & 0.0 & 2.0 & 1.4 \\
\hline
\end{tabular}


yazılarının etkili olup olmadığı konusunda kent okullarında okuyan öğrencilerin \%32.9'u, gecekondu okullarında okuyan öğrencilerin \%67.1'i etkili olduğunu düşünmekteydi $(p<0.001)$. Pasif içicilikle ilgili bilgi düzeylerini değerlendirmek üzere sorduğumuz soruya gecekondu bölgesindeki okul öğrencilerinin daha yüksek oranda "bilmiyorum" yanıtı verdiği saptandı $(p<0.00)$ (Tablo 3).

Ankete katılan öğrencilerin ev ortamında pasif sigara içiciliği değerlendirildiğinde kent okullarında $\% 26.9^{\prime}$ unun, gecekondu okullarında ise \%48.2'sinin sigara dumanına maruz kaldığı saptandı $(p<0.001)$.

Öğrencilerin sigaraya başlama nedenleri sorulduğunda hem kent hem de gecekondu okullarında en sık başlama nedeninin merak, ikinci sırada da arkadaş ısrarı olduğu görüldü (Tablo 4).

Sigara denemeyi etkileyen farklı değişkenlerin bağımsIz risklerini değerlendirmek için lojistik regresyon modeli oluşturulmuştur. Tek başına etkili bulunan değişkenler arasındaki korelasyonlar değerlendirilmiş, yüksek korelasyon gösteren değişkenlerden, sigara deneme üzerinde daha etkili olanların modele alınmasına karar verilmiştir. Cinsiyet, sınıf, anne eğitimi, okulun bulunduğu bölge, baba mesleği, babanın, kardeşlerinin ve en iyi arkadaşının sigara içme durumu modele alınan değişkenlerdir. Modelde sigara denemenin, okulu gecekondu bölgesinde olanlarda 2.07 kat (\%95 GA 1.36-3.15), kardeşinin sigara içtiğini belirtenlerde 1.97 kat (\%95 GA 1.10-3.52) ve en iyi arkadaşının sigara içtiğini belirtenlerde 4.99 kat (\%95 GA 3.13-7.95) daha fazla olduğu saptanmıştır.

\section{TARTIŞMA}

Illimiz ilköğretim okullarında okumakta olan altıncı, yedinci ve sekizinci sınıf öğrencisi toplam 696 öğrencinin katıldığı bu araştırmada öğrencilerin sigara içme prevalansının belirlenmesi, sigara içimini etkileyecek faktörlerin belirlenmesi ve Temmuz 2009 'da yürürlüğe giren tütün mamüllerinin zararlarının önlenmesine dair yasaya karşı tutumlarının değerlendirilmesi amaçlanmıştır. Araştırmaya katılan öğrencilerin sigara içme prevelansı kent okullarında \%1.7, gecekondu okullarında \%15.7, ortalama \%7.1 olarak bulunmuştur. Ülkemizde yapılan çalışmalarda ortaokul öğrencileri arasında sigara içme prevalansı \%4-10.8'dir $(6,7)$. Küresel Yetişkin Tütün Araştırması Türkiye Raporu'na göre gençlerde sigara içme oranı \%8.4'tür (8).

Araştırma kapsamındaki gecekondu okullarında sigara deneme ve içme oranları kent okullarındaki öğrenci- lerden belirgin olarak yüksek saptanmıştır. Bunun başlıca nedenleri olarak bu çocukların düşük sosyoekonomik düzeyde aileye sahip olması, çocuklar üzerinde ailesel destek ve denetimin yetersiz olması, çocukların erken yaşta para kazanmaya başlaması ve çalıştığı ya da yaşadığı çevredeki olumsuz arkadaşlık ilişkileri olabilir.

Sigara içiminin cinsiyetle ilişkisi ülkeden ülkeye, etnik ve kültürel farklara göre değişkenlik göstermektedir. Gelişmekte olan ülkelerde erkek öğrenciler kız öğrencilere göre daha fazla sigara içmektedirler. Amerika, Avrupa ve Batı Akdeniz'de ise sigara içme prevelansı bakımından her iki cins arasında fark bulunmamaktadır (9). Bu nedenle doğu ile batı arasındaki sigara içme farklılığı, cinsiyet farklıığından ziyade kültürel farklııı olarak değerlendirilmelidir. Çalışmamızda Türkiye'de yapılan diğer çalışmalarda olduğu gibi erkek öğrencilerde sigarayı deneme ve içme prevelansı daha yüksek saptanmıştır $(6,10)$. Kent ve gecekondu okulları kendi içlerinde cinsiyet açısından karşılaştırıldığında sigara denemede kent okullarında her iki cins arasında belirgin fark gözlenmezken gecekondu okullarındaki erkek öğrencilerde daha yüksek deneme oranları saptanmıştır. Gecekondu bölgesinde erkek egemen toplum anlayışından kaynaklanan erkek çocuklara tolerans gösterilmesi ve erkek çocukların erken yaşta değişik işlerde çalışmak zorunda kalması sorumlu tutulabilir.

Çalışmamızda sınıf düzeyi arttıkça hem kent hem de gecekondu okullarında sigara deneme ve düzenli içme oranlarının arttığı gözlenmiştir. Bu fark gecekondu okullarında daha fazla göze çarpmaktadır (11). Öğrencilerin adölesan döneme yaklaştıkça büyüdüklerini kanıtlama dürtüsü, sigara içerek özgürleştiklerini sanmaları, özenti ve arkadaş çevresi oluşturma istekleri ileri yaşlarda daha fazla sigara içmelerini açıklayabilir.

Anne ve babanın eğitim durumunun bireylerin sigara içme davranışları üzerindeki etkisi konusunda kültürler arası farklılıklar gözlemlenmiştir. Çalışmamızda tüm öğrenciler birarada değerlendirildiğinde hem sigara deneme hem de sigara içme oranı anne ve baba eğitim düzeyinin düşük olduğu öğrencilerde daha yüksek oranda saptanmıştır.

Tüm okullar genel olarak değerlendirildiğinde baba, kardeş ve en iyi arkadaşının sigara içmesiyle sigara deneme oranları arasında ilişki gözlenmiş, sigara içme oranları karşılaştırıldığında en iyi arkadaşın ve kardeşin sigara kullanmasıyla öğrencilerin sigara kullanımı arasında anlamlı bir ilişki saptanmıştır. Türkiye gene- 
linde (Kayseri, İzmir, Manisa) yapılan çalışmalarda ve çalışmamızda da öğrencilerin sigara içimini etkileyen en önemli faktörün arkadaş çevresi olduğu görülmüştür (12-14). Çevre ve arkadaş faktörü her türlü kötü alışkanlıkta olduğu gibi sigara konusunda da belirleyici olabilmektedir $(15,16)$.

Öğrencilerin sigara yasağına karşı tutumları değerlendirildiğinde 4207 sayılı yasadan kent okullarındaki öğrencilerin daha yüksek oranda haberdar olduğu ve bu yasayı daha yüksek oranda desteklediği saptanmıştır. Bu durum sigara yasağı konusunda eğitim ve bilgilendirme etkinliklerinin gecekondu bölgelerine yoğunlaştırılması gerektiğini göstermesi bakımından önemlidir.

"Genç yaşta içilen sigara alışkanlık yapar mı?" sorumuza öğrencilerin tamamına yakını hem kent hem de gecekondu okullarında evet yanıtını vermişlerdir. Bu durum öğrencilerin sigaranın bağımlılık yapan bir madde olduğu konusunda bilgi sahibi olmalarına karşın sigara içimini sürdürdüklerini göstermektedir.

Sigarayla mücadelede farklı yöntemler izlenmektedir. Ülkemizde sigara paketlerinin üzerinde sigaranın zararlı etkilerini anlatan uyarı yazıları mevcuttur. Hammond ve arkadaşları tarafından, Amerika Birleşik Devletleri, İngiltere, Kanada ve Avustralya'da yapılan ve toplam 9058 kişiyi içeren bir çalışmada sigara paketleri üzerindeki uyarı yazılarının etkinliği incelenmiş, sigara paketlerindeki uyarı yazılarının kalıcı bir eğitici kaynak olduğu bildirilmiştir. Sigaranın zararları hakkında bilgilerin kaynağı sorulmuş, bilgi kaynaklarının en sık televizyon (\%87.7), sigara paketleri (\%64.6) ve yazılı medya (\%64.1) olduğu belirtilmiştir (17). Çalışmamızda sigaranın etkilerini anlatan uyarı yazılarının sigaraya başlama çağındaki öğrenciler üzerinde etkili olup olmadığı konusundaki sorumuza gecekondu bölgesindeki öğrenciler kent okullarındakilere göre daha yüksek oranda etkili olarak yanıt vermişlerdir. Bu durum, bu bölgedeki yüksek içme oranları nedeniyle bu öğrencilerin daha sık olarak bu yazılarla karşılaşmasıyla açıklanabilir.

Çalışmamızda öğrencilerin üçte birinden fazlasının ev ortamında sigara dumanına maruz kaldığı saptanmıştır. Bu durum gecekondu bölgesi okulunda okuyan öğrencilerde çok daha belirgindir. Çalışmamızda gecekondu bölge çocuklarının pasif sigara içiciliği hakkındaki bilgi düzeyinin daha az olduğu saptanmıştır. Tüm sağlık risklerinin yanında pasif sigara içiciliğinin çocuklardaki en önemli etkilerinden birisi de ileri yaşlarda sigara içme üzerindeki etkisidir. Araştırmalar, pasif içici çocukların $\% 74^{\prime}$ ünün daha sonra aktif içici olduğunu ve \%65'inin çocuklarının yanında sigara içtiğini göstermiştir.

Kesitsel çalışmanın doğasından kaynaklanan neden sonuç ilişkisinin yönünün net olarak verilememesi çalışmamızın kısıtlılığını oluşturmaktadır.

Çalışmamızda hem kent hem de gecekondu bölgelerinde öğrenciler sigaraya başlamalarının en önemli nedenini merak ve arkadaş ısrarı olarak belirtmişlerdir. Ayrıca gecekondu bölgesinde üzüntü faktörünün de sigaraya başlamada önemli bir neden olduğu göze çarpmaktadır. Bu durum, bu bölgede yaşayanların ekonomik sorunları ve bu sorunlar nedeniyle aile içi iletişimsizlik ve geçimsizlikleriyle ilişkili olabilir. Aile içinde yaşanan ekonomik ve sosyal sorunların çoçukların sigara içmesinde rol oynaması nedeniyle sorunun çözümü için yalnızca çocuğu değil, aile ve çocuğu birlikte ele alan programların uygulanması önem kazanmaktadır.

\section{Öneriler}

Öğrenciler sigaranın sağlık, kişisel bütçe, ülke ekonomisi, uzun ve kısa vadeli toplumsal etkileri konusunda bilgilendirilmelidirler. Bu bilgilendirme ilköğretimde müfredata sigara içerikli derslerin konması ya da periyodik kampanyalar yapılmasıyla sağlanabilir. Sigaraya karşı yürütülecek etkinliklere özellikle sigara içen ve gecekondu bölgesinde yaşayan öğrencilerin aktif olarak katılmaları sağlanmalıdır.

\section{EK 1}

Manisa ili ilköğretim okullarında sigara içme prevelansı anketi:

Merhaba;

Bu araştırma ile ilimizdeki ilköğretim öğrencilerinin sigara içme sıklığı ve sigaraya karşı tutumlarını saptamayı amaçladık.

Bu açıdan ankette sorulan soruları dikkatle okuman ve sana uyan seçenekleri yanıtlaman bizim için çok önemli. Ankette kimliğiniz ile ilgili hiçbir bilgi yer almamaktadır. Vereceğiniz cevaplar kesinlikle gizli tutulacaktır.

Cevaplarınızı içten ve doğru olarak vermeniz çalışma sonuçlarının toplum için faydalı bir bilgi olarak kullanımasını sağlayacaktır. Yanlıs veya aldatıcı bilgi verirseniz tüm çabalar boşa gidecektir.

Yardımınız için teşekkür ederiz. 


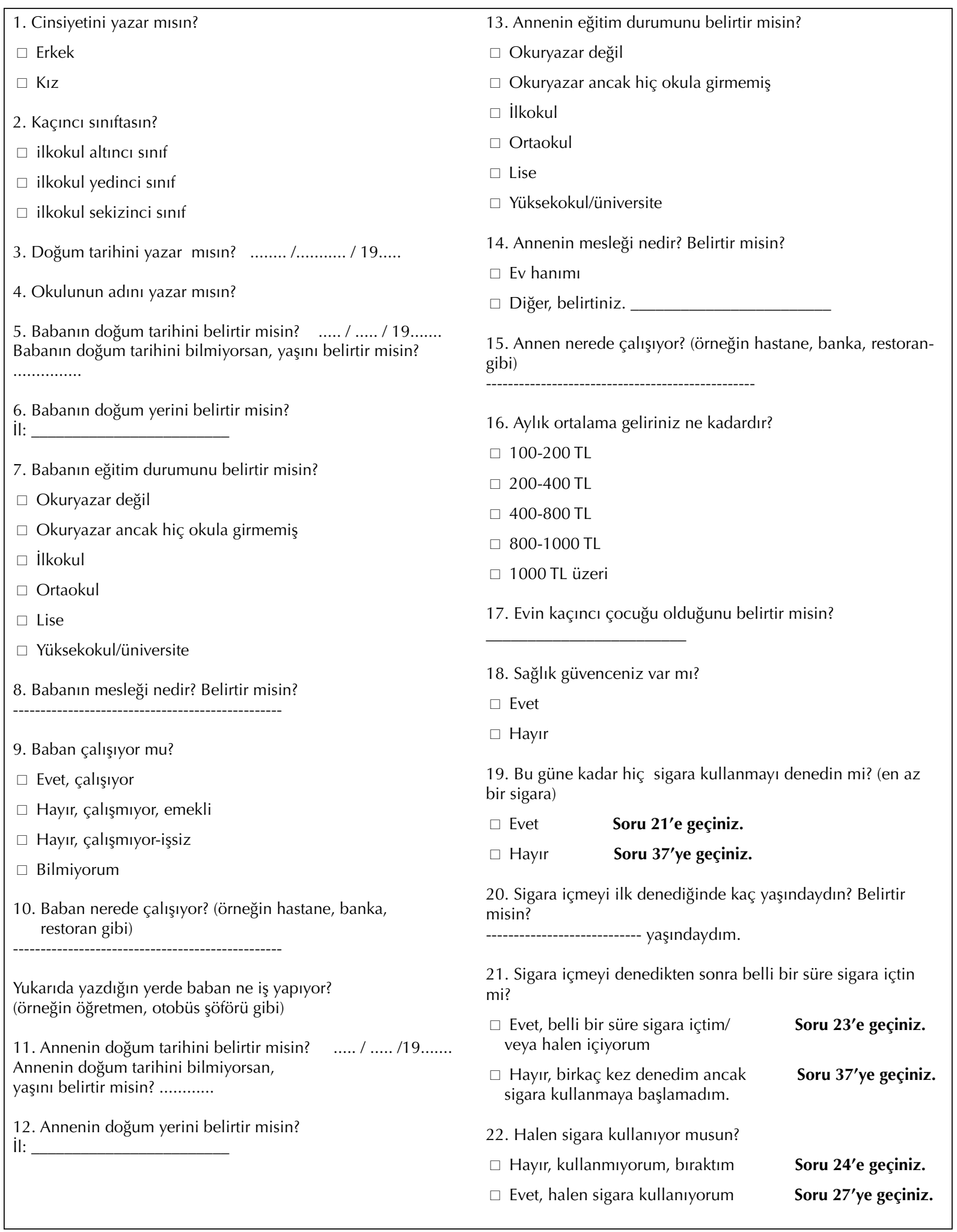




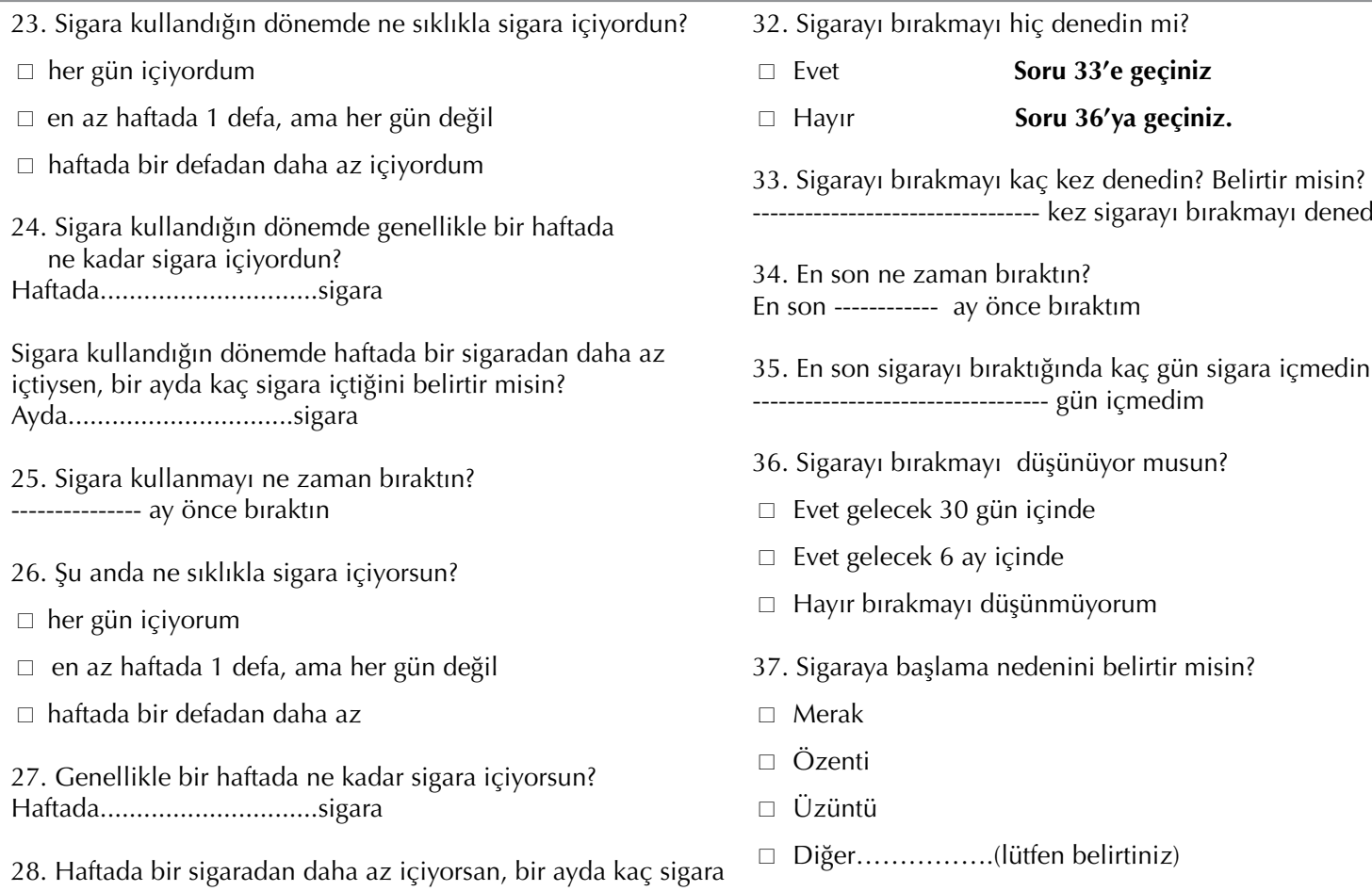

28. Haftada bir sigaradan daha az içiyorsan, bir ayda kaç sigara

32. Sigarayı bırakmayı hiç denedin mi?

$\square$ Evet

Soru 33'e geçiniz

$\square$ Hayır

Soru $36^{\prime}$ ya geçiniz.

33. Sigarayı bırakmayı kaç kez denedin? Belirtir misin?

34. En son ne zaman bıraktın? En son ay önce bıraktım - gün içmedim

36. Sigarayı bırakmayı düşünüyor musun?

$\square$ Evet gelecek 30 gün içinde

$\square$ Evet gelecek 6 ay içinde

$\square$ Hayır bırakmayı düşünmüyorum

37. Sigaraya başlama nedenini belirtir misin?

$\square$ Merak

$\square$ Özenti

$\square$ Üzüntü

Diğer. .(lütfen belirtiniz) içtiğini belirtir misin?

Ayda. sigara

29. Bir sigara içme gereksinimi hissetmeden ne kadar süre dayanabilirsin?

$\square \quad 1$ saatten daha az dayanabilirim

$\square$ 1-3 saat dayanabilirim

$\square 3$ saatten daha çok ama bir günden daha az dayanabilirim

$\square$ Tüm gün dayanabilirim

$\square$ Birkaç gün ama bir haftadan daha az dayanabilirim

$\square$ Bir hafta dayanabilirim

$\square$ Bir haftadan daha uzun bir süre dayanabilirim

30. Evde sigara içmene izin veriliyor mu?

$\square$ evet, her zaman

$\square$ evet, bazen

$\square$ hayır, hiçbir zaman

31. Aşağıdaki durumlarda ne sıklıkla sigara içersin? Hiç Nadiren Bazen Sıklıkla

\section{Yalnızken}

Arkadaşlarımla

Babamla

Annemle - kez sigarayı bırakmayı denedim

35. En son sigarayı bıraktığında kaç gün sigara içmedin?

38. Aşağıdaki kişilerden sigara içen var mı?

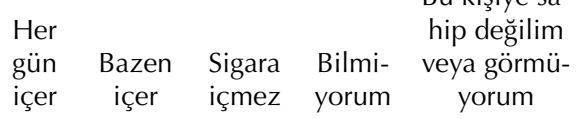

Annen

Baban

Kardeşin/

kardeşle-

rin

En iyi

arkadaşın/

ların

39. Arkadaşlarının ne kadarı sigara içiyor?

$\square$ Hepsi ya da tamamına yakını

$\square$ Yarısından çoğu

Yarısı

Yarısından daha az

$\square$ Çoğu içmiyor

$\square$ Hiç biri içmiyor 


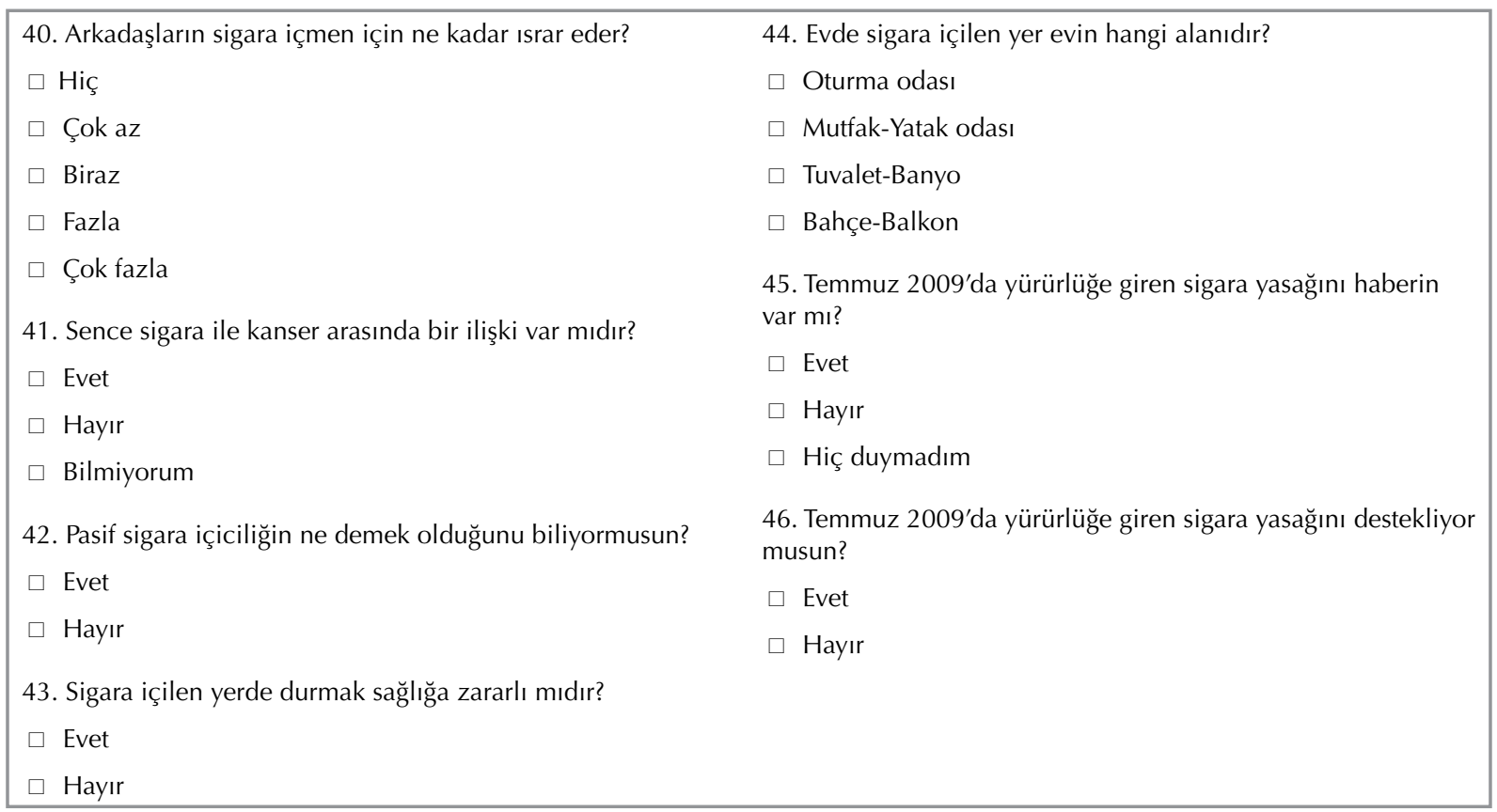

\section{KAYNAKLAR}

1. Zetterstrom O, Nordvall SL, Bjorksten B, Ahlstedt $S$, Stelander $M$. Increased IgE antibody responses in rats exposed to tobacco smoke. I Allergy Clin Immunol 1985;75:594-8.

2. Pierce JP, Naquin M, Gilpin E, Giovino G, Mills S, Marcus S. Smoking initiation in the United States: a role for worksite and college smoking bans. I Natl Cancer Inst 1991;83:1009-13.

3. Molyneux A, Lewis S, Antoniak M, Browne W, McNeill A, Godfrey C, et al. Prospective study of the effect of exposure to other smokers in high school tutor groups on the risk of incident smoking in adolescence. Am / Epidemiol 2004; 159:127-32.

4. Alexander C, Piazza M, Mekos D, Valente T. Peers, schools, and adolescent cigarette smoking. I Adolesc Health $2001 ; 29: 22-30$

5. Buller DB, Borland R, Woodal WG, Hall JR, Burris-Woodall $P$, Voeks $\mathrm{JH}$. Understanding factors that infl uence smoking uptake. Tob Control 2003;12(Supp/ 4):16-25.

6. Kocabaş A. Orta dereceli okul öğrencilerinde sigara içme alışkanlığı. Ankara Tıp Mecmuası 1988;41:9-22.

7. Emekdar G, Çıtıl R, Önder Y, Bulut YE, Yaşayancan Ö, Kazancı NÖ, et al. Tokat ili ortaokul ve lise öğrencilerinde sigara içme prevalansı ve etkileyen faktörler. J Contemp Med 2017;7.

8. Küresel Yetişkin Tütün Araştırması Türkiye Raporu, Ankara, 2012. http://www.halksagligiens.hacettepe.edu.tr/KYTA_ TR.pdf (ErişimTarihi:Mayıs 2016).
9. Use of cigarettes and other tobacco products among students aged 13-15 years-worldwide, 1999-2005. MMWR Morb Mortal Wkly Rep 2006;55:553.

10. Ertas N. Factors associated with stages of cigarette smoking among Turkish youth. Eur J Public Health 2005;15:404-10.

11. Berkem N, Ipek M, Eylen B, Ercan I, Berkem G, Sürücü H et al. Öğrenciler arasında madde kullanımı yaygınlığının ve özeliklerinin belirlenmesi araştırması; Bursa Sağlık Müdürlüğ̈̈ yayınları no:5, Bursa 2002. ISBN:075-585245-X.

12. Çelik P, Esen A,Yorgancıŏ̆lu A, Şen FS, Topçu F. Manisa ilinde lise öğrencilerinin sigaraya karşı tutumları. Toraks Dergisi 2000;1:61-6.

13. Ergüder T, Soydal T, Uğurlu $M$ ve ark. Küresel gençlik tütün araştırması Türkiye. Sağıık Bakanlığı Madde Bağımlılı̆̆ı Şube Müdürlüğü 2003.

14. Oymak FS, Gülmez i, Çetinkaya F ve ark. Kayseri'de kolej öğrencilerinde sigara içme alışkanlığı. Erciyes Tıp Dergisi 1998;20:214-9.

15. Kodjo CM, Klein JD. Prevention and risk of adolescent substance abuse the rol of adolescents, families and comminities. Pediatr Clin North America 2002;49:257-68.

16. O'Loughlin J, O'Loughlin EK, Wellman RJ, Sylvestre MP, Dugas EN, Chagnon $M$, et al. Predictors of cigarette smoking initiation in early, middle, and late adolescence. Journal of Adolescent Health 2017;61:363-70.

17. Hammond D, Fong GT, McNeill A, Borland R, Cummingset $K M$. Effectiveness of cigarette warning labels in informing smokers about the risks of smoking: findings from the international tobacco control (ITC) four country survey. Tobacco Control 2006;15(Suppl III):iii19-iii25. 